\title{
Perancangan Sensor Gerak Benda pada Benturan Berlebihan untuk Pengujian Pre-Straining Spring Momentum Exchange Impact Dumper (PSMEID) dengan Metoda Prediksi Waktu Benturan (Preview)
}

\author{
Darmawan $^{1^{*}}$, Lovelyson $^{2}$ dan Pharmayeni ${ }^{3}$ \\ ${ }^{1}$ Jurusan Teknik Elektro, Fakultas Teknik, Universitas Andalas, Padang, Sumatera Barat, Indonesia \\ ${ }^{2}$ Jurusan Teknik Mesin, Fakultas Teknik, Universitas Andalas, Padang, Sumatera Barat, Indonesia \\ ${ }^{3}$ Program Studi Teknik Industri Agro, Politeknik ATI, Padang, Sumatera Barat, Indonesia \\ *Corresponding author, e-mail: wawan@eng.unand.ac.id
}

\begin{abstract}
Abstrak - Getaran yang terjadi diakibatkan oleh benturan yang berlebihan (Excessive Impact) dapat merusak kontruksi sebuah benda. Excessive Impact yang biasanya terjadi pada waktu tertentu saja seperti benturan roda pendaratan pesawat dengan landasan pacu yang dapat berakibat fatal jika getaran yang dihasilkan tidak dapat dikontrol dengan baik. Penelitian ini mencoba merancang simulasi sebuah system peredaman untuk mereduksi getaran yang terjadi akibat dari Excessive Impact. Metoda yang dikembangkan disebut sebagai PSMEID (Pre-Straining Momentum Exchange Impact Dumper), dimana dalam hal ini memanfaat momentum dari sebuah masa yang ditempatkan pada masa utama yang arah gayanya berlawanan dengan gaya yang dihasilkan oleh benturan dari Excessive impact. Pada penelitian ini akan dilakukan dengan mensimulasikan Excessive impact dengan cara memprediksi waktu benturan sehingga waktu pelepasan massa dengan dorongan pegas yang sudah diregangkan (pre-straining) dengan arah yang berlawanan dari arah benturan memberikan hasil yang lebih optimal untuk mereduksi getaran dari benturan yang terjadi. Dengan peracangan sensor vibrasi dan gerak maka didapat waktu tercepat solenoid mengaktifkan PSMEID adalah 32 milisecon.
\end{abstract}

Kata Kunci : Excessive Impact, PSMEID

\begin{abstract}
Vibration that occurs due to excessive impact can damage the construction of an object. Excessive Impact which usually occurs only at certain times, such as aircraft landing gear collisions with runways that can be fatal if the vibrations produced cannot be controlled properly. This study to design a simulation of a damping system to reduce vibrations that occur as a result of Excessive Impact. The method developed is referred to PSMEID (Pre-Straining Momentum Exchange Impact Dumper), which in this case utilizes momentum from a period placed in the main period in which the direction of the style is opposite to the force generated by the impact of the Excessive impact. This research will be conducted by simulating the Excessive impact by predicting the time of the collision so that the time of mass release with a spring push that has been stretched (pre-straining) in the opposite direction from the direction of the collision gives more optimal results to reduce vibrations from the impact.
\end{abstract}

Keywords : Excessive Impact, PSMEID

\section{Pendahuluan}

Vibrasi atau getaran adalah gerak berisolasi, membalas, yang periodik pada titik setimbang yang disebabkan karena adanya gaya eksternal yang bekerja pada benda yang kaku atau elastis. Vibrasi dapat sangat merusak sebuah benda ketika gagal diisolasi oleh struktur benda tersebut, peristiwa yang paling terkenal adalah hancurnya jembatan Tacoma di USA pada tahun 1941 setelah beroperasi selama 4 bulan. Dalam beberapa dasawarsa ini, penelitiaan tentang pengontrolan/isolasi vibrasi menjadi subjek yang sangat penting dalam pengembangan perancangan mesin yang memiliki performansi tinggi dan struktur sebuah bangunan. Pembangunan gedung-gedung bertingkat juga memerlukan analisa isoalasi vibrasi yang baik karena gaya ekternal terhadap gedung tersebut seperti dorongan angin yang kuat, gempa bumi dan beban dinamik lainnya memungkinkan dapat merusak struktur bangunan tersebut secara keseluruhan. Pengontrolan vibrasi juga diperlukan pada kendaraan bermotor karena tingkat vibrasi 
menjadi ukuran untuk kenyaman dan keamanan saat kendaraan itu dijalankan dan pada pesawat udara selama proses terbang dan pendaratan. Vibrasi pada sebuah massa sangat bergantung pada sistem suspense yang melekat pada massa tersebut. Sistem suspensi dapat mereduksi vibrasi yang terjadi disebabkan permbukaan jalan yang tidak rata $^{1}$, dan hal sebalik juga terjadi ketika tekanan yang belebihan akibat perancangan sistem suspensi dapat merusak permukaan jalan [1]. Beberapa Kajian berfokus pada mereduksi kerusakan jalan dengan mengoptimalkan perancangan sistem suspensi sudah dilakukan [2],[3]. Beberapa tahun belakangan ini, Untuk perancangan algoritma pengontrolan vibrasi dan sistem suspensi mendapat perhatian yang sangat besar [4].

Perancangan sistem suspensi pada kendaraan bermotor seperti pada mobil, sepeda motor, kereta api telah memasuki fase dimana kenyaman dan keamanan menjadi perhatian utama. Penggunaan sistem suspensi berjenis pasif yang terdiri dari pegas dan peredam masih banyak diterapkan karena biaya produksi yang lebih rendah serta perancangan sistem yang lebih sederhana. Penggunaan sistem pasif untuk kendaraan yang relative memiliki beban lebih ringan menjadi umum digunakan dibandingkan penggunaan sistem control aktif yang biasa digunakan pada beban berat yang memerlukan kemampuan menyerap energi benturan lebih besar, seperti pada roda pendaratan pesawat terbang. Sistem control aktif pada suspensi relatif memiliki biaya lebih mahal dan sistem yang lebih rumit dan melibat sistem elektro-mekanis seperti pada penelitian Hac [5] pada tahun 1985 yang menggunakan electro-hydrolic pada sebuah sistem suspensi. Limitasi dari sistem aktif control untuk mengontrol berbagai variasi vibrasi yang terjadi sudah pernah diteliti oleh Karnopp (1983, 1986) [6],[7], Hedrick (1990) [8] dan William (1997) [9] dengan menggunakan dua parameter yaitu kekakuan roda dan perbandingan berat roda dan badan kendaraan. Sistem control untuk suspensi aktif cendrung memiliki respon yang lambat karena melibatkan penggunaa actuator aktif dan penelitian tentang pengaruh waktu tunda terhadap proses aktifasi actuator pada sistem aktif control akan membatasi pengguaan sistem control ini pada beberapa aplikasi saja[10].[11].

Dengan keterbatasan sistem control aktif pada waktu tunda pada respon aktifasi actuator diatas maka beberapa penelitian sudah mengembangkan mekanisme baru yaitu dengan tetap menggunakan sistem pasif yang diutilisasikan yang disebut sebagai MEID (Momentum Exchange Impact Dumper). MEID menggunakan metoda perbedaan momentum berdasarkan teori ayunan Newton. Konsep dasar dari MEID seperti yang digambarkan pada gambar 1 dibuat dari teori benturan tiga bola, dimana bola pertama dianggap sebagai gaya eksitasi atau eksternal dari luar yang membentur massa utama yang dipresentasikan oleh bola kedua, sedangkan bola ketiga mempresentasikan massa damper yang berfungsi mereduksi energi kinetic yang dipindahkan dari bola kedua menggunakan metoda perubahan momentum.

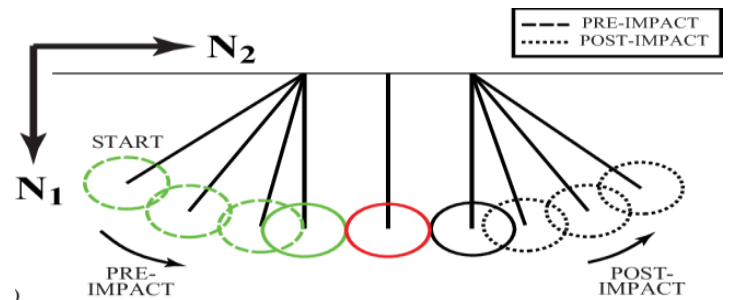

Gambar 1. Metoda benturan 3 bola berdasarkan teori ayunan newton [12]

Metoda MEID seperti yang digambarkan oleh gambar 2 dianggap mampu mereduksi akselerasi maksimum pada vibrasi [13] dan dapat diaplikasikan pada benda seperti mesin tempah dan roda pendaratan pada pesawat terbang [13]. Pada sistem PMEID, perpindahaan energi maksimum dari massa utama kepada massa peredam memiliki durasi yang sama dengan benturan dari massa damper ke massa utama [13]. Karena kecilnya energi yang dilepaskan oleh MEID sistem ke arah massa utama, maka beberapa peneliti mencoba menambahkan actuator pada sistem MEID yang disebut sebagai metoda AMEID (Active Momentum Exchange Impact Dumper). Pada kenyataannya sangat sulit untuk bagi aktuator untuk menghasil gaya besar yang ketika kontak di lakukan [14].

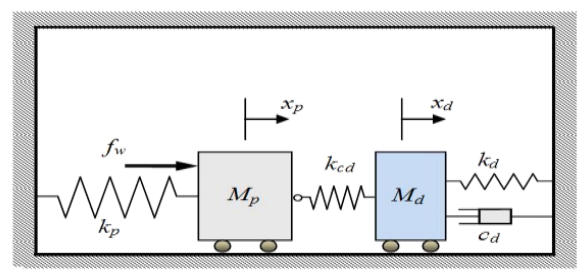

Gambar 2. Satu derajat kebebasan sistem PMEID [15]

Dengan keterbatasan yang dimiliki oleh sistem AMEID dan PMEID maka diperkenalkan metoda baru memanfaatkan energi potensial yang terdapat pada pegas yang ditekan yang disebut sebagai Prestraining Spring. Pre-straining Spring terletak antara massa utama dan massa peredam yang 
diperkirakan mampu memberikan gaya lawan lebih besar terhadap massa utama ketika benturan terjadi, metoda ini disebut sebagai PSMEID (Pre-straining Spring Momentum Exchange Impact Dumper). Sistem mekanisme dumper PSMEID digambar pada gambar 3 .

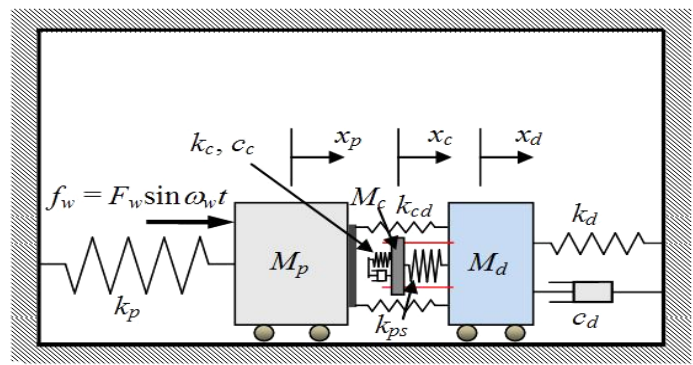

Gambar 3. Satu derajat kebebasan sistem PSMEID [15]

Proses gaya yang disalurkan pada PSMEID yang disimulasikan dilakukan pada sebuah penelitian oleh L.son 2018 yang berjudul "A new concept for UAV landing gear shock vibration control using pre-straining spring momentum exchange impact damper". Dalam penelitian tersebut dinyatakan bahwa maksimum gaya yang disalurkan ketika terjadi benturan pada roda pendaratan dan permukaan tanah terjadi pada waktu 0.15 detik setelah benturan dengan simulasi tanpa dumper dan menggunakan PMEID seperti yang ditampilkan oleh gambar dibawah gambar 4. Dalam menggunakan PSMEID disimulasikan benturan pertama terjadi pada waktu 0.083 detik dan penyaluran daya maksimal serta percepatan maksimum pada massa utama terjadi pada 0.14 detik. Dari data grafis pada gambar 4 maka PSMEID dapat mereduksi penyaluran gaya sebesar 6 persen dibanding PMEID yang hanya mampu mereduksi hingga 1 persen dan mereduksi percepatan vibrasi 13,5 persen dibanding penggunaan PMEID 2.5 persen.

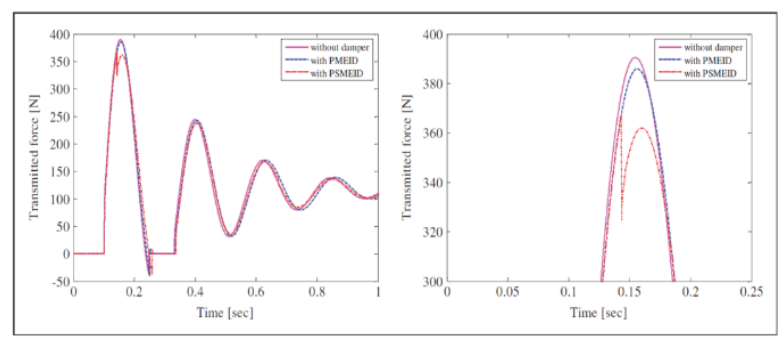

Gambar 4. Penyaluran gaya pada massa utama selama terjadi benturan [15]
Sistem suspensi aktif dengan metoda prediksi waktu benturan pernah dikembangkan oleh Tanaka [17] seperti yang digambarkan pada gambar 5 . Dalam metoda ini, sebuah sensor optic diletakkan antara massa ekternal dengan massa utama yang fungsinya medeteksi gerakan dari massa ekternal. Aktuator terdiri dari massa dumper, yang terpasang dengan kuat pada batang dorong. Beban awal menggunakan defleksi awal pegas koil diterapkan pada batang. Lendutan pegas koil terus-menerus dilakukan dengan menggunakan penjepit, yang digerakkan oleh gaya hidrolik. Batang awalnya diposisikan pada ruang bebas kecil dari massa utama. Ketika massa ekternal membentur massa utama, gaya impulsif yang diberikan oleh massa ekternal menetralkan energi kinetik dari batang, yang dihasilkan dengan melepaskan pegas yang mendapat tekanan.

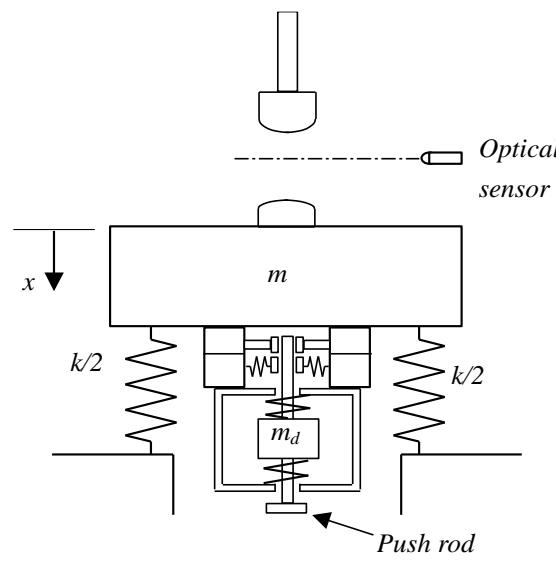

Gambar 5. Sistem suspense aktif dengan prediksi waktu benturan

\section{Sistem Kontrol Vibrasi}

Secara umum, ada tiga kategori jenis suspensi untuk mereduksi vibrasi yang sudah dikembangkan sampai dengan saat ini antara lain suspensi pasif, suspensi semi-aktif, suspensi aktif dengan sistem hidrolik/pneumatic dan suspensi aktif dengan elektromagnetik. Ketiga sistem suspensi tersebut memiliki kelebihan dan kekurangan masingmasing sesuai dengan aplikasinya. Sistem pasif tentunya yang pertama kali dikembangkan seperti yang terlihat pada gambar 6 . Sistem pasif sangat sederhana dan mudah diaplikasikan, karena tidak membutuhkan energi listrik dari luar untuk bekerja, sehingga ketergantungan kepada sistem/proses lain menjadi minimal. 


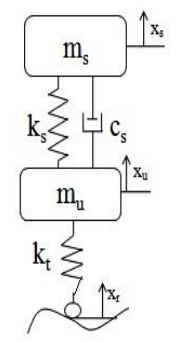

(a)

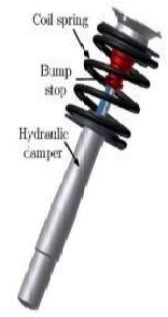

(b)
Gambar 6. Model Suspensi Pasif (a) dan Suspensi pasif komersial (b)

Sistem pasif masih menjadi pilihan utama saat ini karena biaya pembuatan yang relatif murah dibanding kategori lain, perancangan yang lebih sederhana dan memiliki reliabilitas yang tinggi. Suspensi dengan sistem pasif umumnya diaplikasikan pada kendaraan bermotor dan gedung. Respon sistem suspensi pasif di tentukan oleh dua variabel yang dapat diatur sedemikian rupa, yaitu konstanta pegas dan koefisien redaman. Sistem suspensi pasif memiliki performansi yang sangat baik ketika frekuensi tinggi dan koefisien redaman diatur pada rentang yang rendah, hal tersebut berlaku sebaliknya. Frekwuensi rendah sesuai dengan koefisien redaman yang tinggi.

Beberapa penelitian sudah dilakukan terkait performansi dari sistem pasif ini diantara Ankita R. Bhise pada tahun 2016, melakukan perbandingan antara suspensi pasif dan semi-aktif, dimana suspensi pasif hanya mampu memberikan redaman 63,7\% untuk persentasi fluktuasi pada massa sprung dilain pihak, suspensi aktif mampu memberikan performansi $93,9 \%$. Penelitian lain untuk meningkat performansi pasif suspensi dilakukan dengan menentukan nilai koefisien redaman di tentukan menggunakan metoda PDD (position dependent damping). Aplikasi penggunaan sistem pasif juga digunakan untuk konstuksi bangunan, penelitian yang terkait dengan perancangan sistem pasif yang disebut sebagai pasif bar dumper untuk bangunan tahan gempah ${ }^{18}$.

Disamping sistem pasif yang masih terus dikembangkan, sistem kontrol aktif pada vibrasi juga telah berkembang dengan pesat yang dimulai pada tahun 1968 oleh Bender, yang melakukan kajian sistem kontrol untuk aplikasi suspensi kendaraan. Tahun 1973, Crosby dan karnopp memperkenalkan konsep redaman aktif (aktif dumper), mereka menggunakan metoda kontrol dengan umpan balik berkecapatan tetap untuk sistem kontrol. Karnopp pada tahun 1984 dan Redfield pada tahun 1989 melakukan kajian tentang pengaruh konstanta pegas terhadap suspensi aktif.

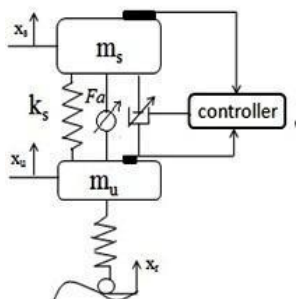

(a)

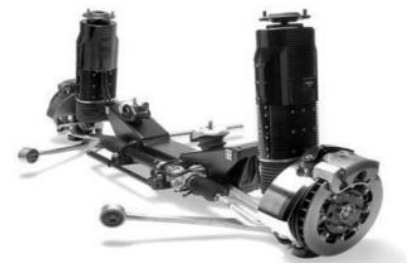

(b)
Gambar 7. Model dasar Suspensi Aktif (a) Prototipe dari electromagnetic active suspension buatan Bose Corporation (b).

Pada sistem suspensi aktif, terdapat actuator yang berfungsi sebagai pengontrol gaya dorong ke massa utama atau pengontrol fungsi peredam sehingga vibrasi dapat direduksi dengan baik. Pada gambar 8. diatas $\mathrm{Fa}$ adalah sebuah actuator yang dapat berupa hidrolik, pneumatik atau elektromagnetik, atau sistem hybrid. Jenis aktuator yang tersebut diatas dapat bekerja pada frekwensi tinggi jika dipasangkan sejajar dengan pegas dan damper, sebaliknya jika frekwensi rendah pegas dan damper akan aktif untuk mereduksi getaran. Biaya suspensi aktif tergantung pada bandwidth yang disediakan, semakin besar bandwidth yang tersedia makan biaya akan semakin besar. Pengontrol Fa dapat dilakukan dengan algoritma pengontrol seperti PID, kontrol adaptif dan kontrol kekokohan [18].

Gaya dan energy pada vibrasi dapat dikontrol dengan baik menggunakan sistem kontrol aktif dan sistem hybrid, akan tetapi sistem ini memiliki biaya yang relative lebih mahal, design yang komplek serta kesetabilan yang terbatas pada beberapa aplikasi. Karena itu dikembangkan sistem suspensi menggunakan metoda kontrol semi-aktif yang mana konstanta pegas adalah tetap dan kooefisien peredam dapat ditentu sesuai dengan beban vibrasi yang terjadi. Karnop dan Crosby pada tahun 1974 memperkenalkan konsep kontrol semi-aktif pada suspensi dan sistem struktur. Dumper yang dapat dikontrol dapat berupa hydrolic dumper, electrohydrolic dumper, magnetorheological (MR) dumper fluid.

Dalam kontrol semi-aktif, mengoptimal kinerja kontroler seperti pada gambar 8. untuk mengatur koefisien dumper. Beberapa penelitian terkait dengan optimasi kontroler pada pengontrolan koefisiean damper diantaranya 
menggunakan LQR (linear quadratic regurator) oleh dan nonlinear stochastic sebagai kontrolernya.

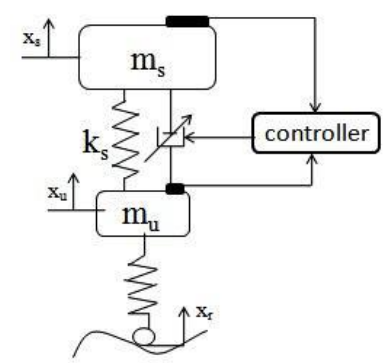

(a)

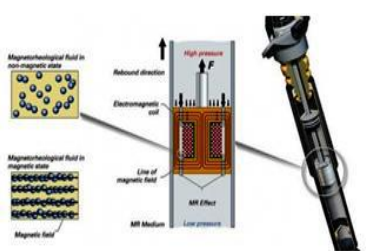

(b)
Gambar 8. Model dasar Semi-aktif suspensi (a) MR dumper (b)

\section{Perancangan Sistem Suspensi PSMEID untuk UAV}

Perkembangan penelitian tentang kontrol vibrasi melalui perancangan sistem suspensi telah memasuki fasa dimana sistem pasif diutilisasi menggunakan metoda lain, sebagai contoh penggunaan perubahan momentum yang disebut sebagai MEID. MEID sendiri dibagi menjadi 2 kategori, yaitu PMEID dan AMEID. PMEID adalah sistem suspensi passive yang menggunakan perubahan momentum dimana energi kinetic yang dihasil ketika tumbuhkan pada massa utama akan ditransfer ke massa yang bertindak sebagai redaman passive. Sedangkan pada AMEID, sistem dumpernya digantikan oleh actuator dapat berubah hidrolik, pneumatic dan magnetorheological dumper.

PSMEID adalah satu metoda baru untuk mereduksi vibrasi yang terjadi setelah benturan antara roda pendaratan dan permukaa tanah. Perubahan momentum yang terjadi ketika bola pertama bertumbukan dengan bola kedua adalah sama dengan besaran momentum ketika bola kedua bertumbukan dengan bola ketiga, begitu seterusnya bola ketiga memberikan tumbukkan dengan kepada bola kedua, sehingga posisi bola kedua akan selalu tetap. Pada proses PSMEID, bola kedua dianggap sebagai massa dari UAV, sedangkan massa benda pertama dianggap sebagai permukaan tanah dan massa benda ketiga anggap sebagai gayanya diberikan oleh pegas yang sudah memiliki regangan awal yang di sebut sebagai Pre-Staining Spring.

Model dari sistem roda pendaratan dengan dapat disederhanakan seperti pada gambar 9. UAV memiliki massa utama yang dinyatakan dalam $M_{p}$ yang ditopang lansung oleh roda pendaratan yang memiliki massa $M_{w}$ dan konstanta pegas $k_{w}$ dan konstanta dumper $c_{w}$, dimana antara kedua massa UAV dan roda pendaratan ditempatkan sebuah pegas dengan konstanta $k_{p}$ dan damper dengan konstanta $c_{p}$.

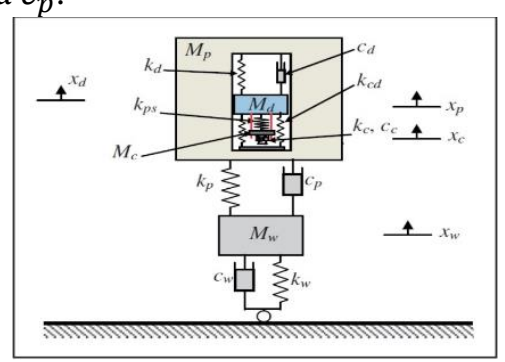

Gambar 9. Sistem PSMEID pada roda pendaratan [15]

\section{Metodologi}

Untuk mengetahui apakah sistem PSMEID dengan memprediksi waktu benturan (preview) dapat mereduksi percepatan vibrasi yang terjadi, maka dilakukan ekperimental dan simulasi guna membukti berbagai asumsi tentang berbedaan waktu momentum dan energi momentum yang dilibatkan. Pada proses ekperimen dilakukan beberapa tahapan untuk menghitung beberapa parameter yang menunjukkan performasinya vibrasi yang terjadi diantaranya percepatan, simpangan, dan energi. Tahapan yang akan dilaksanakan terdiri dari:

a. Perancangan sistem sensor dan data akusisi.

b. Menguji dan kalibrasi sistem sensor yang akan digunakan.

c. Pengambilan data tunda terbaik dan dengan variasi nilai konstanta pegas pada PSMEID yang diubah guna menetukan yang terbaik dalam meredam vibrasi yang terjadi dengan mengubah beberapa variable seperti percepatan.

d. Memvariasikan percepatan benturan dari gaya ekternal untuk menganalisa

e. Menganalisa pengaruh waktu aktivasi PSMEID pada parameter frekwensi, penyaluran gaya, simpangan maksimum, dan energi yang dipindahkan.

f. Melakukan simulasi PSMEID yang dalam berbagai kondisi seperti peracangan PSMEID untuk roda pendaratan UAV. 


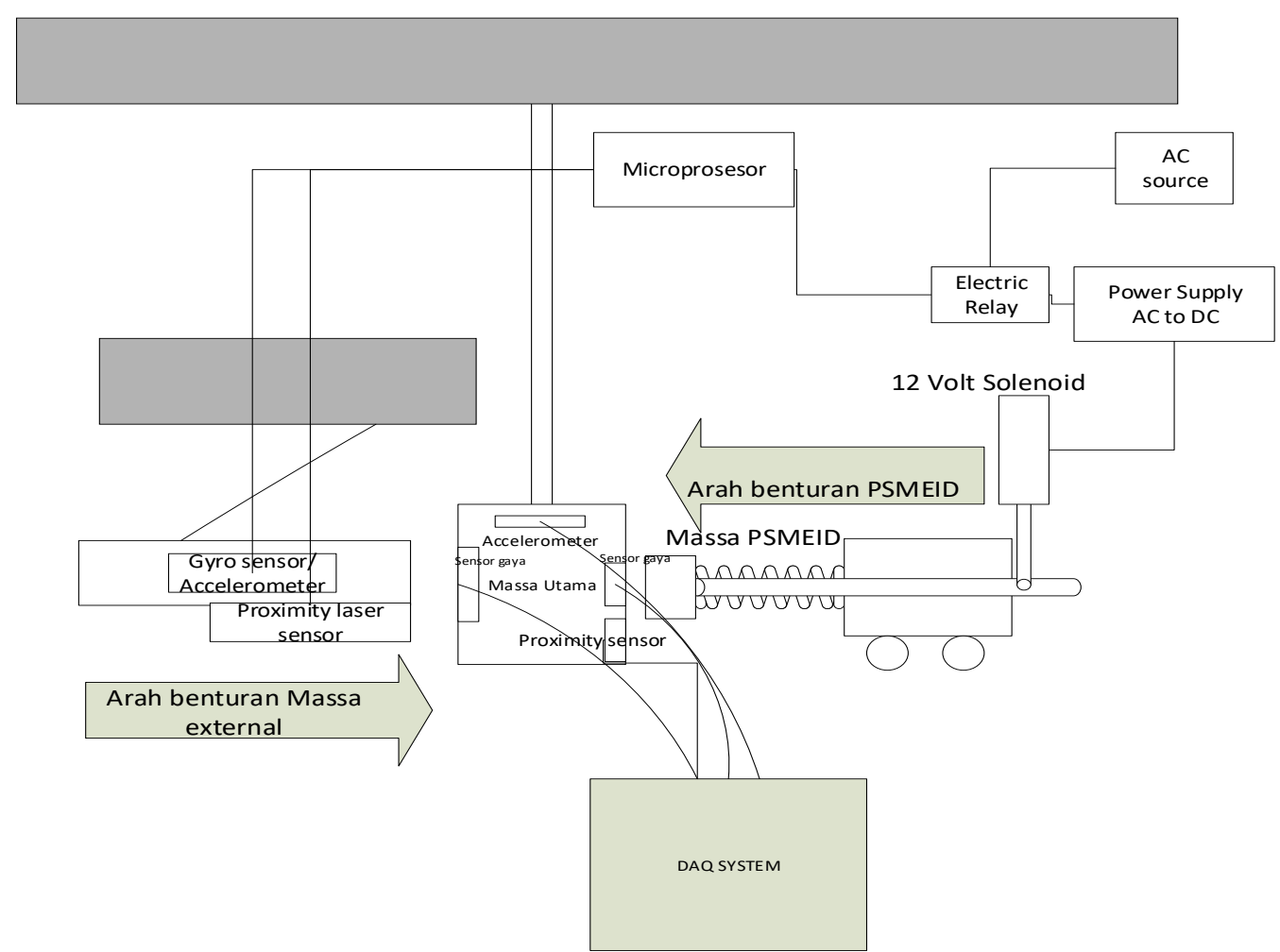

Gambar 10 Perancangan ekperimen sistem PSMEID dengan prediksi waktu benturan

Diagram Eksperimen sistem PSMEID yang akan dilaksanakan pada penelitian ini digambarkan pada gambar 10. Ada 3 jenis massa yang digunakan, yaitu massa utama, massa ini yang akan dideteksi percepatan, frekwensi, simpangan dan energi vibrasi yang terlibat didalamnya. Massa kedua di sebut sebagai massa ekternal, yang memberikan gaya ekternal kepada massa utama, dalam simulasi ekperimen tentunya massa ini bias diubah nilai tergantung nilai besaran gaya yang ingin kita benturkan kepada massa utama. Massa yang ketiga adalah massa dumper yang memberikan gaya berlawanan dengan massa ekternal.

Massa utama dan massa ekternal dilengkapi oleh beberapa sensor. Pada massa utama dilengkapi oleh 3 jenis sensor yang memberikan informasi besaran gaya dan energi yang dipindahkan dari massa ekternal kepada massa utama ketika terjadi benturan, sensor berjenis sama terletak pada sisi yang berlawanan untuk mendeteksi gaya dan energi pada saat massa dumper memberikan saya yang berlawanan kepada massa utama. Massa utama juga dilengkapi dengan sensor accelerometer untuk mengetahui percepatan massa saat dan setelah terjadi benturan dan proximity sensor untuk mengetahui simpangan maksimum atau puncak gelombang vibrasi yang terjadi. Ketiga jenis sensor tersebut akan terhubung kedalam sebuah data akusisi NI 9861.

Massa ekternal dilengkapi dengan 2 jenis sensor, yang memberikan informasi tentang percepatan massa ekternal dan jaraknya massa ekternal ke massa utama. Kedua sensor tersebut akan menentukan percepatan dan kecepatan saat saat terjadi benturan, sehingga dapat ditentukan energi yang dihasilkan ketika benturan terjadi. Sensor jarak dapat memberikan informasi estimasi waktu benturan yang terjadi antara massa ekternal dan massa utama sehingga controler dapat memerintahkan solenoid untuk melepaskan sekatan pada pegas PSMEID. Dorongan besar yang memiki energi potensial inilah yang memberikan gaya kepada massa damper untuk membentuk massa utama dari sisi yang berlawanan.

\section{HASIL DAN PEMBAHASAN}

Berdasarkan penelitian suspensi aktif dengan prediksi waktu benturan diatas maka dalam penelitian ini akan mencoba melakukan kajian pada sistem PSMEID yang sudah dijelaskan sebelumnya dengan menggunakan metoda prediksi waktu benturan (Preview) dari gaya ekternal ke massa utama sehingga didapatkan waktu optimal untuk 
mengeksitasi PSMEID membentur massa utama. Pengaruh waktu PSMEID dalam simulasi dan ekperimen akan ditinjau dari beberapa parameter vibrasi diantara pergerakan maksimum yang terjadi, pengaruh nilai konstanta pegas, pengaruh koefisien redaman, frekwensi vibrasi, gaya yang disalurkan dan energi yang berubah. PSMEID dengan prediksi waktu benturan diharapkan dapat mereduksi percepatan vibrasi dan gaya yang disalurkan selama terjadi benturan. Jika grafik PSMEID tanpa prediksi waktu benturan dianggap seperti pada gambar 6, maka pada PSMEID dengan prediksi waktu benturan, waktu tunda antara benturan massa dumper ke massa utama dapat diperkecil secara signifikan.

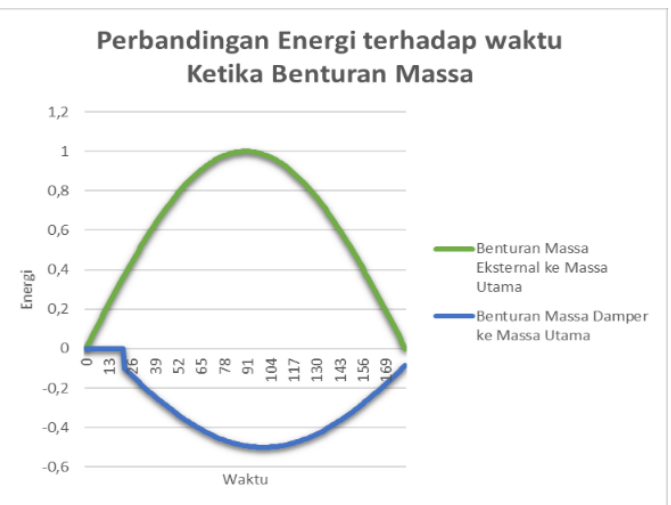

Gambar 11. Contoh penyaluraan gaya pada sistem PSMEID tanpa prediksi waktu benturan

Dari pengujian yang dilakukan, didapatkan waktu estimasi terbaik antara waktu terjadinya benturan pada massa utama sehingga waktu yang diperlukan oleh oleh relay untuk mengaktifkan PSMEID pada ekperimen didalam diperlukan waktu kecil dari $30 \mathrm{~ms}$. Seperti yang terdapat pada gambar 12.

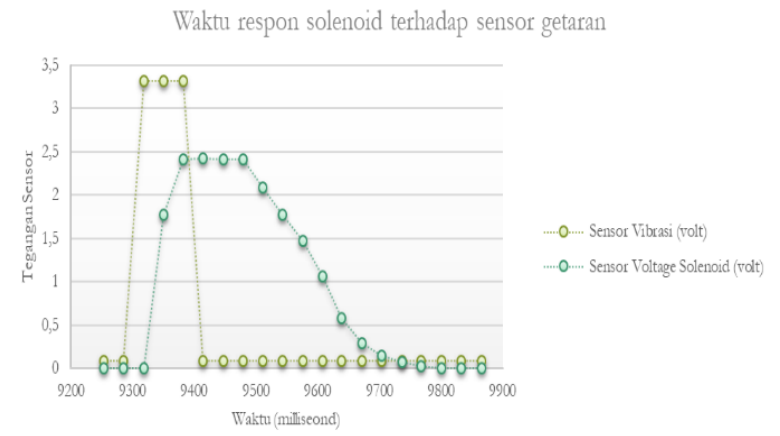

Gambar 12. Waktu respon solenoid terhadap sensor getaran

Dari gambar 12 terlihat tegangan getaran yang terdeteksi oleh data akusisi berwarna kuning dan tegangan tegangan solenoid untuk mengaktifkan PSMEID berwarna hijau. Tegangan terdeteksi oleh sensor getaran dan gerak pada waktu $9318 \mathrm{~ms}$ dan Tegangan solenoid pada $9350 \mathrm{~ms}$ ditunjukkan oleh pada cursur diatas. Selisi antara sensor gerak dan vibrasi dengan aktivasi solenoid pada PSMEID berkisar pada $32 \mathrm{~ms}$.

\section{KESIMPULAN}

Penelitian ini sudah mampu merancang sensor gerakan dengan menghasilkan kecepatan dan percepatan benda saat terjadi benturan yang berlebihan. Selonoid mampu di aktifkan oleh system untuk menggerakan PSMEID guna memberikan gerakan yang berlawan dengan arah benturan terjadi setelah $32 \mathrm{~ms}$ setelah benturan terjadi.

\section{Daftar Pustaka}

[1] Hrovat, D 1981, “Optimum Vehicle suspensions minimizinn RMS rattleplace, sprung-mass acceleration and jerk", ASME Journal of Dynamic System, Measurement and Control, vol 103, no 3, pp 228-236.

[2] Cole D.J dan Cebon D, 1992, "validation of an articulated vehicle simulation, Vehicle System Dynamics”, vol 21, no 2 pp 197-223.

[3] Code DJ, Cebon D dan Besinger, F.H, 1994, "Optimisation of passive and semi-active heavy vehicle suspensions", SAE 942309.

[4] Cole DJ, 2001, "Fundamental issue in suspension design for heavy road vehicle, vehicle system dynamics, vol 35, no 4-5, pp. 319-360.

[5] Hac, A, 1985, "Design of Disturbance decoupled observer for bilinear systems, ASME Journal of Dynamic System, Measurement and Control, vol 114 no 4 pp. 556-562.

[6] Karnopp, D.C, 1983, "active damping in road vehicle suspension systems, vehicle system dynamics, Vol 12, No 2. Pp. 291-316.

[7] Karnopp, D.C, 1986, "Theoretical Limitations in active vehicle suspensions, vehicle system Dynamics", Vol 15, No 1.pp. 41-54.

[8] Hedrick, J.K, Butsuen, 1990, “ Invariant properties of automotive suspensions", Proceeding of the Institution of Mechanical Engineers, Part D, Vol 217, No 12, pp. 10951106. 
[9] William, R.A,"Automotive active suspensions, Part 1: basic principles", Proceeding of Institution of mechanical Engineers, Part D, Vol 211, No 6, pp. 415426.

[10] Hac. A., Youn, I., 1993, “Optimal design of active and semi-active suspensions including time delays and preview", ASME journal of vibration and Acoustic, Vol 115, No. 4. Pp.498-508.

[11] Jalili, N, 2001, "Optimum active vehicle suspensions with actuator time delay", ASME Journal of Dynamic System, Measurement and control, Vol 123, No 1,pp. 54-61.

[12] Watanabe, T, 2004, "Study on passive momentum exchange landing gear using two-dimensional analysis", Acta Astronautica 105(2014)407-416.

[13] Son L., Matsuhisa H., and Utsuno H., 2008, "Energy transfer in a three-body momentum exchange impact damper", Journal of System Design and Dynamics, 2 (1), 425441, https://dx.doi.org/10.1299/jsdd.2.425.

[14] Son L., Hara S., Yamada K., and Matsuhisa H, 2009,"Experiment of shock vibration control using active momentum exchange impact damper", Journal of Vibration and Control, $16 \quad$ (1), 49-64, https://dx.doi.org/10.1177/10775463091026 75.

[15] Son L, Mulyadi Bur dan Meifal Rusli, 2018, "A new concept for UAV landing gear shock vibration control using pre-straining spring momentum exchange impact damper", Journal of Vibration and Control 2018, Vol. 24(8) 1455-1468.

[16] Son L, Mulyadi Bur dan Meifal Rusli, 2015, "Fundamental Study of Momentum Exchange Impact Damper Using Prestraining Spring Mechanism", International Journal of Acoustics and Vibration 2015, Vol. 22(4) 442-430.

[17] Tanaka, N., dan Kikushima, Y. 1987, “A Study on the dynamic damper with a preview action( 1 st report, a principle of the dynamic damper with a preview action)", J. Jpn. Soc. Mech. Eng.,(in Japanese), Vol. 52 No.484, C(1986), pp.3176-3183.
[18] Mulla A.A dan Unaune DR, 2013, "Active Suspensions Future Trend of Automotive Suspensions", International Conference on Emerging Trends in Technology and Aplication, ICETTA.

\section{Biodata Penulis}

Darmawan, menyelesaikan studi sarjana Teknik Elektro di Universitas Andalas dan Master bidang Mekatronik di IIUM merupakan staf pengajar di Jurusan Teknik Elektro Univeritas Andalas. Bidang Riset : Wireless sensor, Kontrol Automatik, Komunikasi Data.

Pharmayeni, menyelesaikan studi sarjana Teknik Elektro di Universitas Andalas dan Master bidang Mekatronik di IIUM merupakan staf pengajar di Politeknik ATI Padang. Bidang Riset : Kontrol Automatik. 